Barbara Bonar CHR

\title{
Bibliografia Liturgiczna Online www.alcuinus.org
}

Pod adresem www.alcuinus.org pojawiło się nowe narzędzie wspomagające pracę naukową powstałe z Polskiej Bibliografii Liturgicznej dostępnej na stronie www.liturgista.pl/pbl. Jest to baza danych międzynarodowej literatury liturgicznej połączona z wyszukiwarką. Celem Alcuinusa jest skatalogowanie i udostępnienie jak największej liczby publikacji z dziedziny liturgii. Specyfiką Alcuinusa jest możliwość dostępu nie tylko do opisów bibliograficznych, ale także do spisu zawartości poszczególnych publikacji. W przypadku książek pojawiają się całe spisy treści, a w przypadku czasopism czy dzieł zbiorowych wymienione są wszystkie artykuły z uwzględnieniem ich śródtytułów.

16 lutego 2009 roku baza Alcuinus zawierała łącznie 4388 opisów bibliograficznych, w tym 522 książki, 3724 artykuły, 54 księgi liturgiczne, 88 dokumentów Kościoła i 13 prac doktorskich.

Bibliografia ta powstaje dzięki nielicznej jeszcze grupce pasjonatów miłośników liturgii. Dlatego do odwiedzenia strony www.alcuinus.org zapraszamy nie tylko chętnych do skorzystania z zasobów bazy danych, ale także wolontariuszy, którzy chcieliby pomóc w rozwoju serwisu. Chętnych do współpracy prosimy o kontakt z ks. Dominikiem Ostrowskim, głównym odpowiedzialnym za Bibliografię Liturgiczną Online. 